\title{
Some Concerns About the Canary Islands and the Introduced Species in Forest Stands
}

\author{
José Ramón Arévalo*
}

\author{
Departamento de Ecología, Facultad de Biología, Universidad de La Laguna, La Laguna 38206, España
}

\begin{abstract}
Invasive alien species can have a detrimental economic impact on human enterprises such as agriculture, grazing, forestry and tourist activities. Forest invasive species have been identified as one the major threats to ecosystems and biodiversity, as well as human well-being. In this Hot Issue I have tried to collect information from research groups working on different aspects of forest invasions in the Canary Islands, analyzing the effect at different levels and the interactions of exotic plant species in forest areas. The studies focus on specific species as Acacia farnesiana, Pinus radiata or Phoenix dactylifera as well as the impact of exotic species at forest plant community level. These results could help guide the development of restoration plans, land reclamation and conservation planning in order to increase the protection against exotic species dispersion in the archipelago.
\end{abstract}

Invasiveness by exotic plants on oceanic islands has proven to be higher than that of continental areas [1]. On oceanic islands, many introduced species show a limited distribution, whereas others have colonized wide areas and are pervasive, threatening to take over the remnants of native vegetation $[2,3]$. The higher invasiveness of oceanic islands may be explained by species poverty, disharmony, isolation, small geographic scale and the presence of vacant niches and a particularly strong effect of ecological release [4].

The rate of exotic species in Canary Islands has been estimated at $3-45 \%[5,6]$ of the total flora, indicating the poor knowledge of the islands' flora. Although the Canary Islands present some similarities with respect to other volcanic archipelagos, a main difference can be the relative close proximity of the Canary Islands to the African continent (95 km aprox.) (Fig. 1). Due to that fact, it is difficult for many species, especially for those with very small seeds, such as graminoids, to be classified as native or introduced by artificial means. That may be the main reason for the high difference in values when the rate of introduced species has been calculated. An attempt to resolve this problem has been to classify the species as introduced, probably introduced, native or probably native [7], but this provides poor accuracy of information with regards to the rate of introduced species relative to other parts of the world such as Australia or South Africa. However these problems seem to be relatively easy to resolve in the case of many woody species, whose introduction on the islands has in many cases been very well documented.

In spite of the minor problems with respect to native or exotic classification of woody species, few studies have been published about woody invasive species or concerned with invasion in forests environments. It has been particularly common to consider forests more resistant to invasions than other plant communities [8]. However, it is also true

*Address correspondence to this author at the Departamento de Ecología, Facultad de Biología, Universidad de La Laguna, La Laguna 38206, España; Tel: +34 922318 628; Fax: +34 922318 311; E-mail: jarevalo@ull.es that like other plant communities, forests face many threats. Disturbances can revert their biotic resistance to invasion [9]. Some studies have found that the perception of invasions of forested areas is lower due to mainly the slower absolute rate of invasion. This has lulled researchers into ignoring their potentially severe and long-term impact on forest ecosystems worldwide [8].

Focusing on woody species of the Canary Islands, some restricted studies have been carried out with respect to the Pinus pinea [10], P. radiata [11], Acacia farnesiana [12] or with respect to plant communities invasions, including in those studies the woody species $[13,14]$. Obviously, this set of studies can be considered as underestimating the problem that faces the Canary Islands with the introduction of exotic species. In many cases these studies have revealed that the woody species remain practically in the same area where they were planted although other studies indicate that they are expanding very fast.

\section{NEW RESEARCH AREAS OPENED IN THE CANARY ISLANDS}

Although there is some available information about exotic species in forest areas in the Canary Islands, these studies were basically descriptive, local and suggest different solutions to the problems based more in perceptions than in experimental tests. It is time now to jump into the future and face some of the questions that arise as we try to understand the invasion process in forest areas:

1. What is the effect of a natural disturbance on the prevalence of exotic species?

2. Is the introduction of woody species a way of facilitating the introduction of other invaders?

3. Which is the role that invertebrate and vertebrate dispersals play in the invasion process?

4. Hybridation native-exotic species

5. Interactions of forest invasive species and native invertebrate dispersals 


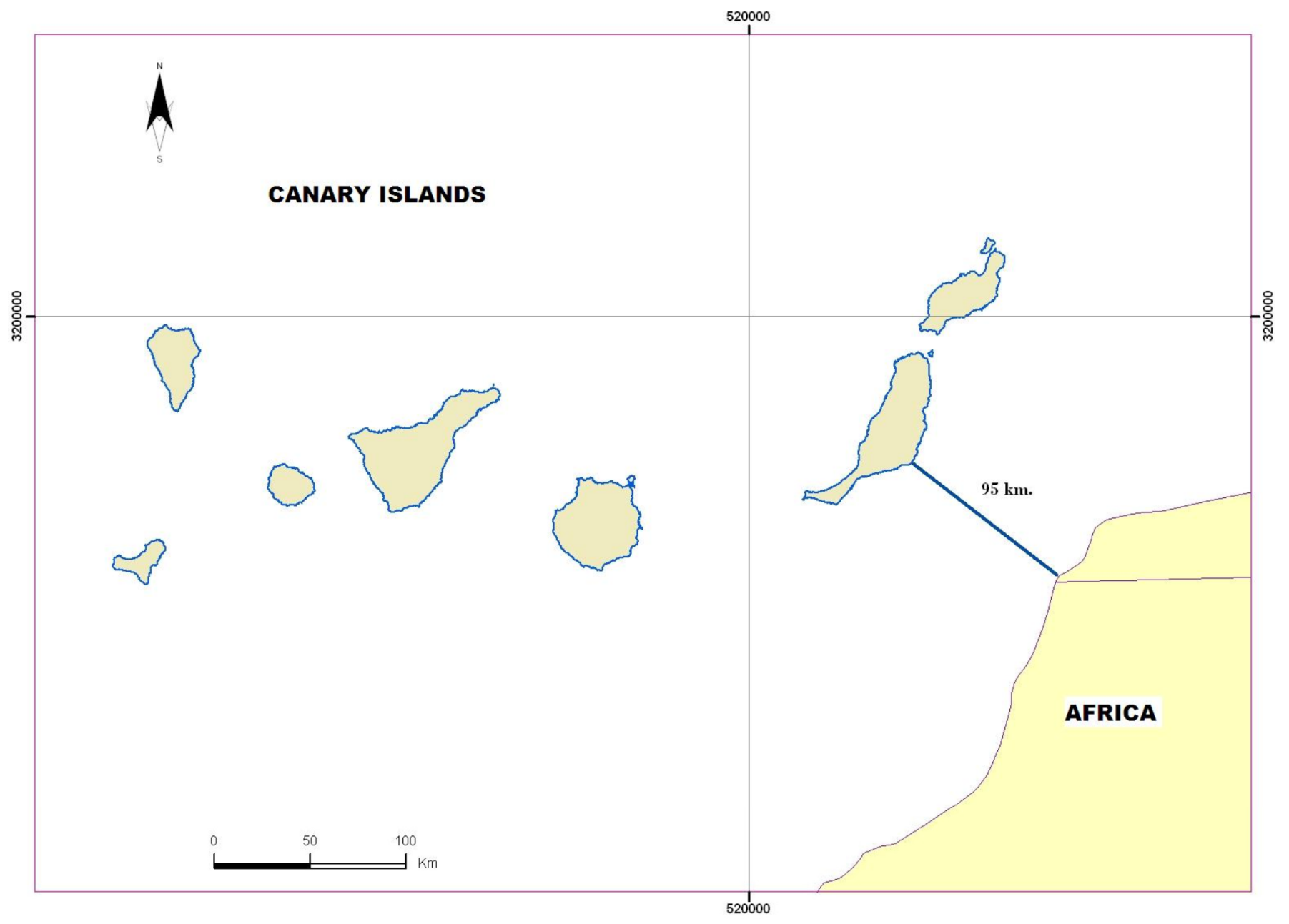

Fig. (1). Canary Islands archipelago indicating the shortest distance from the island of Fuerteventura to the African continent.

In this Hot Issue I have tried to collect information from research groups working on different aspects of forest invasions in the Canary Islands, analyzing the effects at different levels and the interactions of exotic plant species in forest areas.

The manuscript of Fernández-Palacios deals with the effect of natural forest wildfire in the plant communities of Tenerife Island, and to which degree, natural disturbances can be considered a control or a promoting factor for native species. Whilst Fernández-Lugo and Arévalo's study centres on the same island, it analyses the effect that the Pinus radiata plantations can have in the rate of exotic species found in different stands of this species, although with different environmental characteristics.

Jumping to another island of the archipelago, Gran Canaria, two studies dealing with Acacia farnesiana are presented in this Hot Issue. One of the studies (Marcos et al.) presents the role of vertebrates in the dispersion of this species, making it a successful invader and accelerating the occupancy of new areas for this species. The other study, with the same species (Naranjo et al.), is focused on the habitat preferences of the species and what makes the different microhabitats suitable for the species.

One remarkable study in this Hot Issue analyses the imbrications of exotic species in the ecological web plant- animal interactions (de Nascimento et al.). This is one of the most complex aspects of invasions ecology: once a species has invaded a new area, the imbrications with native species can be so complex that extirpation can become almost impossible at certain levels. Due to that, the best control for invasions is the prevention [15].

The Hot Issue finishes with a genetic study of hybridization of native and exotic species of the genus Phoenix (González-Pérez and Sosa). As it has been well documented, imbrications of exotic species do not just affect interactions between animals, also these imbrications are able to modify the genetic diversity of the system.

These studies provide new information that can encourage other groups to explore new research lines in this field. Far from diminishing, problems induced by plant invasions will increase in the future due to deforestation, land degradation, pollution or global change.

\section{REFERENCES}

[1] D'Antonio CM, Dudley TL. Biological invasions as agents of change on islands versus mainlands. Ecol Stud 1995; 115: 103-21.

[2] Ralph CJ, Maxwell BD. Relative effects of human and feral hog disturbance on a wet forest in Hawaii. Biol Conserv 1984; 30: 291303.

[3] Vitousek PM, Loope LL, Stone CP. Introduced species in Hawaii: Biological effects and opportunities for ecological research. Trends Ecol Evol 1987; 2: 224-7. 
[4] Cronk QCB, Fuller JL. Plant Invaders. The threat to natural ecosystems. London: Chapman and Hall 1995.

[5] Vilà M, López-Darias M. Contrasting biogeography of endemic and alien plant species in the Canary Islands. Orsis 2006; 22: 91101.

[6] Salas M, Naranjo A, Arévalo JR. Las plantas exóticas e invasoras de las Islas Canarias. Quercus 2006; 242: 30-4.

[7] Izquierdo I, Martín JL, Zurita N, Arechavaleta M, Eds. Lista de Especies Silvestres de Canarias. Hongos, Plantas y Animales. Consejería de Política Territorial y Medio Ambiente, Gobierno de Canarias: S/C de Tenerife 2001

[8] Martin P, Canham DD, Marks PL. Why forests appear resistant to exotic plant invasions: intentional introductions stand dynamics, and the role of shade tolerance. Front Ecol Environ 2009; 7: 142-9.

[9] Levine JM, Alder PB, Yelenik SG. A meta-analysis of biotic resistance to exotic plant invasions. Ecol Lett 2004; 7: 975-89.

[10] Arévalo JR, Naranjo A, Salas M. Regeneration in a mixed stand of native Pinus canariensis and introduce Pinus pinea species. Acta Oecol 2005; 28: 87-94.
[11] Arévalo JR, Fernández-Palacios JM. Gradient analysis of exotic Pinus radiata plantations and potential restoration of natural vegetation in Tenerife, Canary Islands (Spain). Acta Oecol 2005; 27: $1-8$.

[12] Arévalo JR, Agudo L, Naranjo A, Salas M. Fast invasion and progression of Acacia farnesiana in southern Gran Canaria (Canary Islands). Plant Ecol 2009; DOI 10.1007/s11258-009-9633-0.

[13] Arévalo JR, Delgado JD, Otto R, Naranjo A, Salas M, FernándezPalacios JM. Distribution of alien $v s$ native plant species in roadside communities along an altitudinal gradient in Tenerife and Gran Canaria (Canary Islands). Perspect Plant Ecol Evol Syst 2005; 7: 185-202.

[14] Arteaga M, Delgado JD, Otto R, Fernández-Palacios JM, Arévalo JR. Topography and edge disturbance interact with elevation to determine alien plant distribution along roads on oceanic islands. Biol Invasions 2009; 11: 1071-86.

[15] Perrings C, Dehnen-Schmutz K, Touza J, Williamson M. How to manage biological invasions under globalization. Trends Ecol Evol $2005 ; 20: 212-5$.

(C) José Ramón Arévalo; Licensee Bentham Open.

This is an open access article licensed under the terms of the Creative Commons Attribution Non-Commercial License (http://creativecommons.org/licenses/by$\mathrm{nc} / 3.0 /$ ) which permits unrestricted, non-commercial use, distribution and reproduction in any medium, provided the work is properly cited. 